\title{
The Great Famine: A Simple General Equilibrium Model
}

\author{
PAT McGREGOR* \\ University of Ulster, Belfast
}

Abstract: A general equilibrium model of a poor peasant economy is developed in this paper, one where subsistence is the major concern of many and the absence of a capital market leads to the production possibilities of each agent being constrained by his current resources. A famine situation is then characterised by a wage rate that is below subsistence though the wage-rent ratio is raised. The latter explains why the Famine saw a rapid expansion in livestock production. Despite the low wage, public works facilitated the inter-temporal allocation of resources by the better-off. The government response was to reduce the wage rate so that the poor starved.

\section{INTRODUCTION}

$\mathrm{I}$ $t$ is now almost a century and a half since the decimation of the Irish potato crop by the fungus Phytophtora infestans initiated the sequence of events that culminated in the Great Famine. The potato was the linchpin of the pre-Famine rural economy when it has been estimated that $2.1 \mathrm{~m}$ acres were grown (Mokyr, 1981), accounting for one-third of land under tillage and one-seventh of it under cultivation. The crop was produced intensively, generally on a small scale by smallholders or labourers who sublet land from larger farmers. The blight led to a human deluge that engulfed the various attempts of the British government to provide a system of relief (see O'Gráda, 1989). It has been estimated (Mokyr, 1980) that $1.1 \mathrm{~m}$ perished (out of a population of $8.2 \mathrm{~m}$ in 1841 ) and that a similar number emigrated despite appalling conditions.

Paper presented at the Ninth Annual Conference of the Irish Economic Association.

*The author is grateful to Siddiq Osmani and the conference participants for their comments though the remaining deficiencies are the author's sole responsibility. 
This paper develops a simple general equilibrium model of famine (in the spirit of Sen's, 1981, entitlement approach) to analyse the tragedy that developed in Ireland after the blight attacks and seeks in particular to answer three questions: why did the system of relief works, which at their peak employed three-quarters of a million men and women, attract so many of those whom the officials considered not destitute? Why did the works fail so utterly in their objective? The famine period saw an understandably sharp decline in crop production but alongside this occurred a remarkable expansion of cattle and sheep - what was the economic rationale of this?

The model of the rural economy advanced in this paper is built around three markets, those for food, labour and land and is developed in Section II. This is followed by a detailed analysis of the impact of the blight upon these markets concentrating upon the labour market. In Section IV the model is developed to examine the consequences of the provision of public works. This is followed by our Conclusions where we attempt to answer the questions raised above.

\section{THE MODEL}

We assume that a composite foodstuff, corn, is produced; at the beginning of time period 0 each agent, $i$, possesses an endowment of corn, $\bar{c}_{i, 0}$. To be physically capable of supplying a unit of labour, $c^{*}$ of corn has to be consumed. The market wage $\mathrm{w}$ is a piece rate and so amounts to the return for completing a series of specified tasks such as cultivating a particular acreage of corn.

The alternative to supplying the labour market is to work $l_{i} \leq 1$ on the domestic holding. Such labour, together with $k_{i}$ acres of land produces $\overline{\mathbf{c}}_{i, 1}$ corn in the next time period via a simple Cobb-Douglas production function:

$$
\bar{c}_{i, 1}=\mathrm{dl}_{\mathrm{i}}^{\beta} \mathrm{k}_{\mathrm{i}}^{1-\beta}
$$

The output becomes the agent's endowment for a new optimisation exercise.

The utility function (all agents are identical in this respect) has two arguments; consumption $c_{i}$ of corn only yields utility whenever $c_{i}>c^{*}$. Should consumption fall below $c^{*}$ the household falls into the starvation set - clearly this outcome will be avoided as long as it is feasible to do so.

The other argument of the utility function is $\bar{c}_{i, 1}$ which is the level of endowment anticipated in the second period based on the decisions taken in the first - it is not the level of consumption which can only be determined when factor prices in that period are known. Its magnitude affects optimal allocation in the first period by imparting a sense of security. The utility function is: 


$$
\mathrm{U}_{\mathrm{i}}=\mathrm{b}\left(\mathrm{c}_{\mathrm{i}}-\mathrm{c}^{*}\right)^{1-\mathrm{a}} \overline{\mathrm{c}}_{\mathrm{i}, 1}^{\mathrm{a}}
$$

If the agent falls below $c^{*}$ then they perish; this is a version of the -boiled" solution as outlined by Koopmans in his (1957) survey of the standard model of competitive equilibrium.

The agent's budget constraint reflects his current resource position so:

$$
\left(\bar{c}_{i}-c_{i}\right) p+\left(1-l_{i}\right) w-r_{i} \geq 0
$$

Maximising Equation (2) subject to Equation (3) and the non-negativity constraints $l_{i}, k_{i} \geq 0$ together with $c_{i} \geq c^{*}$ yields a series of demand functions. For food we have:

$$
c_{i}=c^{*}+(1-a) l / p=(1-a) \bar{c}_{i}+a c^{*}+(1-a) w / p
$$

Supply of labour to the market (or demand if $l_{i}>1$ ) is given by:

$$
1-l_{i}=1-a \beta \frac{1}{w}=(1-a \beta)-\frac{a \beta\left(\bar{c}_{i}-c^{*}\right)}{w / p}
$$

As might be expected, supply falls with an increase in endowment, though the agent will supply the food market before he becomes a demander in the labour market. The labour market plays a central role in our analysis of famine so it is worthwhile to highlight several aspects of Equation (5). In Figure 1 we sketch the market schedules for individuals with different levels of endowment. First let us consider two poor labourers with endowments $c^{*}>\bar{c}_{1}>\bar{c}_{2}$. Labour supply will fall for both as the real wage increases essentially the increase in full income is allocated to more production of corn in the next period which will reduce labour supply, even though current consumption of corn will still rise. Since the poor need to purchase corn from the market, they will never become demanders of labour. In fact as the real wage becomes infinitely large, the individual supply schedules of all peasants asymptotically approach 1-a $\beta$, the supply level of an individual with $\overline{\mathrm{c}}_{\mathrm{i}}=\mathrm{c}^{*}$.

Of particular importance is the point at which the supply schedule commences, that is, the lowest real wage $(\mathrm{w} / \mathrm{p})_{i}{ }^{\min }$ at which the peasant is physically capable of participating in the labour market $\left(l_{i}=0\right)$

$$
(w / p)_{i}^{\min }=c^{*}-\bar{c}_{i}
$$

and thus labourer 1 will be able to supply the market for some levels of the real wage at which 2 will be physically incapable of matching (at $w / \mathrm{p}^{*}$, for instance). Should the market wage rate be $\mathrm{w} / \mathrm{p}^{*}$ then those individuals with 


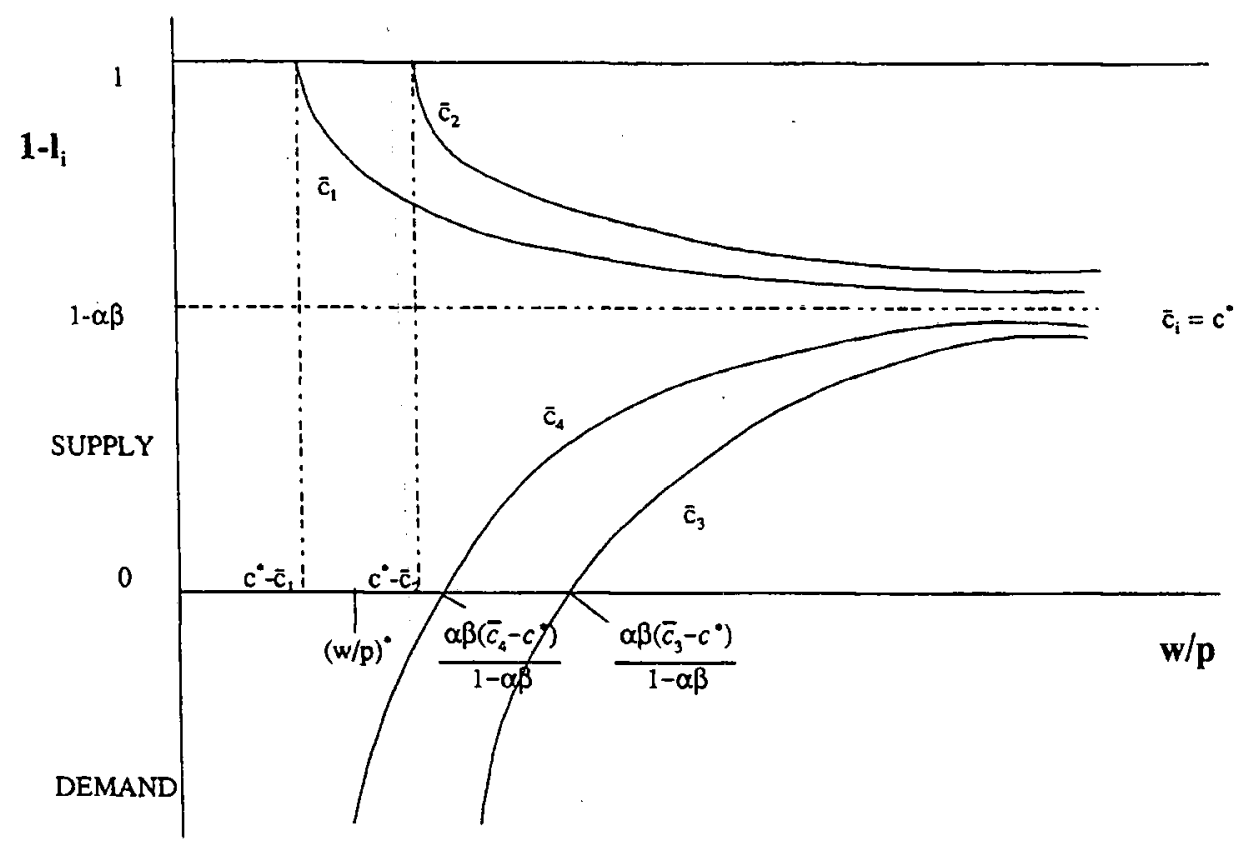

Figure 1: The Individual Supply of Labour

$\bar{c}_{1}$ corn will be labouring while those with $\bar{c}_{2}$ will be facing disaster. The reservation wage falls with endowment, up to $c^{*}$.

Now let us consider the better off, $\overline{\mathbf{c}}_{\mathrm{i}}>\mathrm{c}^{*}$. The wage rate that leads to an individual moving between a supplier and a demander from the market is given by $\frac{a \beta}{1-a \beta}\left(\bar{c}_{i}-c^{*}\right)$. Thus a richer agent will require a higher real wage to become a labourer (as demonstrated on Figure 1 for $\overline{\mathrm{c}}_{3}>\overline{\mathrm{c}}_{4}$ ).

The remaining decision variable is the demand for land which is straightforward since in effect if may be considered simply as a current expenditure to secure future endowment:

$$
\mathrm{k}_{\mathrm{i}}=\frac{(1-\beta) \mathrm{al}}{\mathrm{r}}=\frac{(1-\beta) \mathrm{a}\left(\overline{\mathrm{c}}_{\mathrm{i}}-\mathrm{c}^{*}\right)}{\mathrm{r} / \mathrm{p}}+(1-\beta) \mathrm{aw} / \mathrm{r}
$$

Given that we restrict ourselves to the situation where $l>0$, an increase in the rent level will unambiguously lead to a fall in the demand for land. The three demand Equations (4), (5) and (7) are functions of two real prices, w/p and $r / p$, a point we shall be developing later.

In order to determine equilibrium prices we will start with the labour market where the demand for labour from farmers is met within the agricultural 
sector. As is evident from Figure 1, the wealthier will be demanding labour and the less well-off supplying it. For clarity we will begin with the simple case where $\overline{\mathbf{c}}_{i}>c^{*}$ for all $i=1, . ., N$. Summing Equation (5) over all agents and setting the result to zero yields:

$$
(\mathrm{w} / \mathrm{p})_{\mathrm{e}}=\frac{\mathrm{a} \beta}{1-\mathrm{a} \beta}\left(\overline{\overline{\mathrm{c}}}-\mathrm{c}^{*}\right)
$$

where $\overline{\bar{c}}$ is the mean endowment level in the economy. Inserting Equation (8) into Equation (5) gives (with the e indicating equilibrium throughout)

$$
1-1_{\mathrm{i}}^{\mathrm{e}}=\frac{\mathrm{a} \beta}{1-\mathrm{a} \beta} \frac{\left(\overline{\mathrm{c}}_{\mathrm{i}}-\mathrm{c}^{*}\right)}{\left(\overline{\overline{\mathrm{c}}}-\mathrm{c}^{*}\right)}
$$

Those with endowments above the mean level demand labour while those with less supply it. Should endowments be allocated equally then there are no actors in the market and everyone works full time upon their domestic holding.

We assume land to be held by a class of landlords with the rent level demand determined. Repeating the above exercise with Equation (7) and inserting Equation (8) yields:

$$
(\mathrm{r} / \mathrm{p})_{\mathrm{e}}=\frac{(1-\beta) \mathrm{a}}{1-\mathrm{a} \beta} \frac{\left(\overline{\overline{\mathrm{c}}}-\mathrm{c}^{*}\right)}{\overline{\overline{\mathrm{k}}}}
$$

where $\overline{\overline{\mathbf{k}}}$ is the average quantity of land demanded.

Once the equilibrium real wage rate is determined Equation (4) will generate the corn consumption of every agent and thus his market supply or demand. Equations (9) and (10) determine the wage rate and rent level in terms of corn; the consumption of corn by every agent and thus his market supply or demand, will be determined by Equation (4). The food market consists of the poor purchasing corn from the better-off.

\section{THE IMPACT OF THE BLIGHT}

There were two shocks administered to the Irish rural economy in 1846; the principal one was the blight though in experiencing crop damage Ireland was not alone in Europe. Cereal crop damage was widespread with the result that food prices internationally were bid up. From 54 cents per bushel in July, 1846 the New York price of maize rose to 81 cents in January, 1847 (Bidwell and Falconer, 1925, p. 503). What effect would a price rise have upon the model? 
Equations (8) and (10) give the equilibrium values of $w / p$ and $r / p$ and thus any increase in the price of corn will lead to an equal increase in wages and rents - the equilibrium factor prices in terms of corn are invariant to changes in the price of corn.

However, given the role of the mean endowment level in the equilibrium wage rate and rental it is obvious that the blight will have dramatic effects. The 1846 crop was decimated to about one-quarter of normal yield. The crop constituted about one-fifth of output in a normal year (O'Gráda,1984) and so the blow was exceptionally heavy. Moreover its impact was not evenly distributed. For many labourers the potato was their main or only crop; thus the poor layers of the rural economy suffered disproportionately.

Let us consider then the consequences of a loss of $1-\delta$ of the corn crop due to disease (no attempt will be made to take account of the differential impact). The equilibrium we have characterised above will be disturbed with the extent dependent upon $\delta$. We begin with the labour market because its role is central; for clarity we assume that the wage rate before the shock was $\mathrm{c}^{*}$.

\section{The Labour Market}

The new mean level of endowments is $\delta \overline{\overline{\mathbf{c}}}$ and if the wage rate remains at $c^{*}$, supply of labour to the market will increase and demand will fall. We assume that the result of excess supply of labour is that the wage rate will fall. However, this will lead to a rate below $c^{*}$ and thus one which will not ensure survival unless supplemented by endowment. If the wage rate falls below $(w / p)_{i}^{\min }$ for some $i$ then we must take care that the summation of Equation (5) to generate Equation (8) does not violate Equation (6) for any agent $i$. Provided it is possible to strictly rank all agents by endowment, that is, $\overline{\mathrm{c}}_{1}>\overline{\mathrm{c}}_{2}>\ldots>\overline{\mathrm{c}}_{\mathrm{n}}$, then

$$
(w / p)_{e}=\frac{a \beta}{1-a \beta}\left(\delta \overline{\bar{c}}_{n}-c^{*}\right)
$$

where $\delta \overline{\bar{c}}_{n}$ is the mean endowment of the first $n$ agents and $n$ is the highest integer such that $\delta \bar{c}_{n} \geq c^{*}-\frac{a \beta}{1-a \beta}\left(\delta \overline{\bar{c}}_{n}-c^{*}\right)$. Since the N-n agents with the lowest resources have dropped out, $\delta \overline{\overline{\mathrm{c}}}_{\mathrm{n}}>\delta \overline{\overline{\mathrm{c}}}$.

It is important to fully grasp the implications of Equation (11) for the economic explanation of famine. There is no need for the market clearing wage to guarantee subsistence even though it is rational for every active worker to accept the market rate. To return to Figure 1, we see that for $\bar{c}_{i}<c^{*}$ the reservation wage falls with endowment as the poor workers use 
earnings from the labour market to cover the shortfall in their subsistence consumption. Should the market equilibrium wage be $\mathrm{w} / \mathrm{p}^{*}$ then the better off labourer with $\bar{c}_{i}$ will be working while the one with $\bar{c}_{2}$ will be destitute since $\overline{\mathrm{c}}_{2}+(\mathrm{w} / \mathrm{p})^{*}<\mathrm{c}^{*}$.

We may summarise the effect of the loss of endowments upon the labour market as follows: the consequent reduction in the wage rate will lead to some of the poor being unable to supply labour to the market since the new rate will by itself not afford subsistence and they fall into the starvation set; the reduced wage will lead to a substitution effect in favour of future production but for the poor this is dominated by the income effect which leads them to supply more labour to the market.

\section{The Land Market}

The adjustment here follows directly from that in the labour market. By Equation (7) demand for land will fall as endowments are reduced and the real wage falls - this is reinforced by the destitute dropping out of economic activity. As a consequence there will be excess supply of land services and competitive pressures will bid down the rent level. Moreover, it can be easily demonstrated that the factor prices ratio $\mathrm{w} / \mathrm{r}$ will increase with the endowment loss, in fact $(\mathrm{w} / \mathrm{r})_{\mathrm{F}}=(\mathrm{N} / \mathrm{n})(\mathrm{w} / \mathrm{r})_{\mathrm{e}}$. The intuition behind this is straightforward: the reduction in the wage rate will be achieved by agents dropping out of the labour market and becoming destitute (see O'Gráda, 1974 for evidence). This means that the mean level of endowment of those that remain active will increase providing a brake upon the decline. There is no such brake in the land market and in order to let the land which has become vacant, landlords will reduce the rent level proportionally more than the wage rate has declined - the average size of land let increases. Thus even though the wage rate had been reduced, the technique of production becomes relatively more land intensive.

Although the loss of the potato crop can explain the fall in agricultural output, it is this conclusion of the model that can explain its radical restructuring towards cattle and sheep. In the period 1845-47 the potato acreage declined by 65 per cent, the oat acreage by 18 per cent while the number of cattle increased by 12 per cent. ${ }^{1}$

The crucial characteristic of the famine period is that the wage rate falls below subsistence and to be capable of supplying labour an agent must supplement the wage by some of his endowment. Those with insufficient endowments fall into the starvation set. The endowment loss reduces the

1 The tillage figures are based upon O'Grada (1989, Table 3.3) and the official returns; the livestock figures take account of Bourke's (1965) observations on the 1841 Census. The increase in livestock numbers indicates the resilience of at least some sectors of the rural economy. 
demand for land but competitive pressure leads to the rent level falling by more than the wage rate, with the result that production becomes more land intensive despite the presence of unemployment. The character of the food market is unaltered, though the quantities traded are obviously reduced.

\section{IMPLICATIONS FOR THE RELIEF WORKS}

The traditional policy to alleviate distress in pre-Famine Ireland was the provision of public works (a policy with many distinguished contemporary adherents, see Drèze and Sen, 1989). Given that a large number in the rural economy were rendered destitute by the blight, it is clear that to fulfil the role of combating famine the wage rate on the public works would have to be at $c^{*}$. However, a wage lower than this would attract the participation of an agent whose endowments were such that domestic production was undertaken. Thus the crucial flaw in the relief scheme; accepting a job on the relief works did not necessarily imply destitution. Moreover, if the works were attracting those who were not destitute, then the conclusion for the administrators was straightforward: the wage rate was too high.

The principal vehicle was the Labour Rate Act under which employment grew from 30,000 in October, 1846 to a peak of 710,000 the following March. Only one person per family was originally to be employed though this was subsequently relaxed as the crisis developed. Still the extent of the operation, given a population of 8.2 million in 1841 , was vast.

The intention of the Act was that wages were to be set at a level below that prevailing in a locality. In the Pre-Famine rural economy wages were often not paid in money but rather were entered notionally at an agreed rate in a complex deal including house, turbary, grazing and potato land. According to the Poor Inquiry (Appendix D), the winter wage rate without food was $8.26 \mathrm{~d}^{2}$ with a standard deviation of $1.51 \mathrm{~d}$. The rise in food prices would have led to such a level being totally inadequate and by October wages were being increased with task work introduced to deter applicants, though intimidation often rendered this impotent.

In fact the imposition of task work made the situation worse. Gangs made up of fitter men would refuse to have any weak starving people put in with them and so could exploit the task work system. Those most in need were disadvantaged - a recurrent criticism of relief by public works (Clay, 1986). The total failure of the wage policy was well expressed by one of its officials:

instead of fitting the wages to the task, we were obliged to fix a rate of wages, such as would give even to starving people a sufficient sum to

$212 \mathrm{~d}=5$ new pence. 
subsist upon; the whole conditions of every part of the machinery were reversed (Parliamentary Papers, 1852, Vol. 6, Q2176).

Average earnings on the relief works have been estimated from the Parliamentary Papers and are graphed in Figure 2. Two clear patterns emerge; first, earnings seemed to have peaked in December and to have thereafter declined spasmodically, with the sharp fall in January associated with poor weather. This decline occurred alongside the continued expansion of the works and can be interpreted as an administrative response to deter applicants. Second, the period of decline in earnings also witnessed increases in food prices so that by April their real value may not have been much more than half that of November. Given that the latter was not generous it is hardly surprising that the relief works failed utterly in their objective.

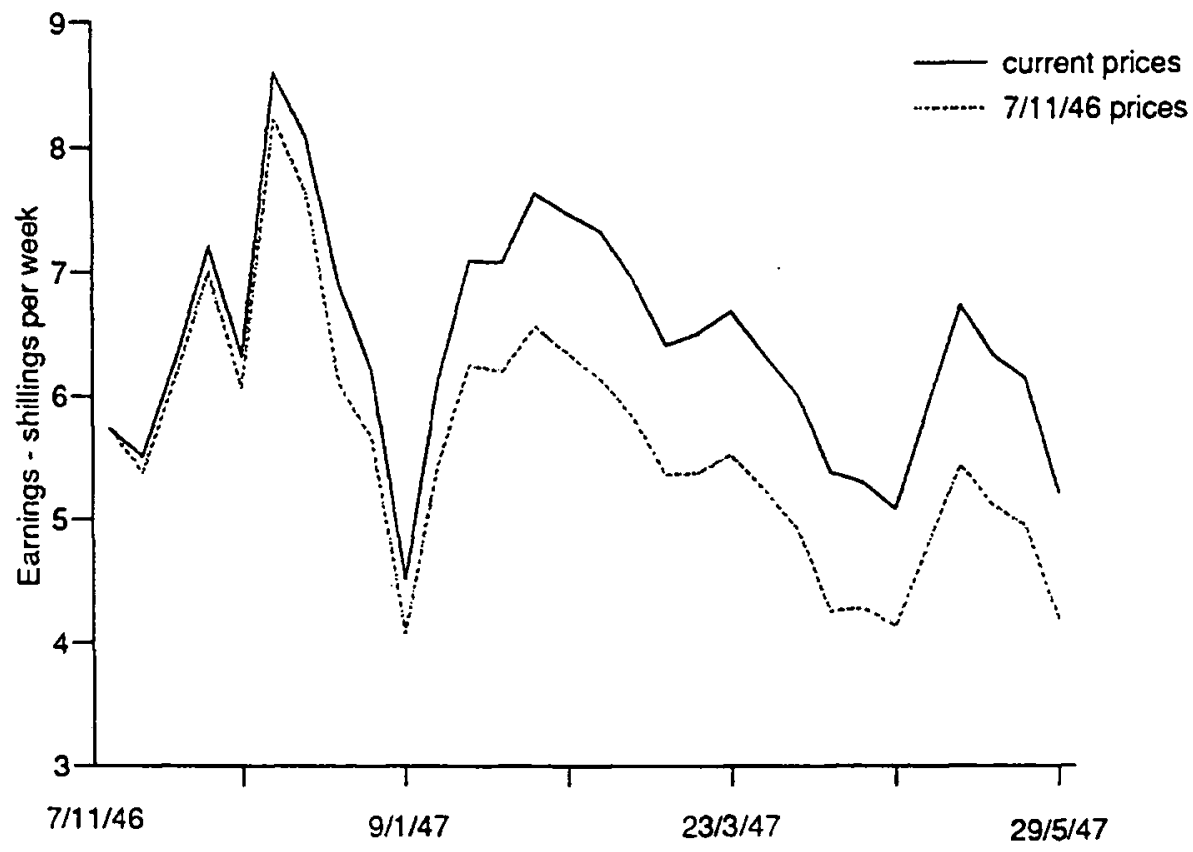

Figure 2: Average Earnings of the Relief Works

Up to 24 April (numbers were reduced sharply thereafter) mean average earnings were 6.44 shillings with a standard deviation of 0.82 . Thus, the daily wage rate would have been $13 \mathrm{~d}$, which, though considerably in excess of the pre-Famine rate, was not disbursed uniformly. Three points require to be highlighted; first, the number employed includes the sick and infirm, as well as women and boys. The wage differentials that existed between these groups may be appreciated from a return from a Monaghan barony where, for the months of December and January, men's wages ranged from 8 to $13.75 \mathrm{~d}$ per 
day, women's 4.0-7.75 and boys 4.0-7.75 (Great Britain, 1847, pp. 48-49).

Second, despite being a sharp increase upon pre-Famine rates, the wages paid by the relief works were inadequate; as the District Engineer in Belturbet noted in February, there had been "a gradual falling off in the earnings of the workmen... the quantity of food which they are able to procure is quite inadequate to enable them to work" (ibid, p. 151). The Board of Works instructions on task work were that an ordinary labourer should earn 10-12d a day, while a good labourer "who exerted himself" could earn 16-18d (ibid, p. 140). Since the poor who were most in need of relief were the most debilitated, the task work regime generated perverse results; the physically fit banded together in gangs to maximise their earnings while the sick and starving perished. The dispersion of earnings on the works were almost as important as the mean.

\section{CONCLUSIONS}

This paper posed three questions concerning the Great Irish Famine; the simple general equilibrium model that has been developed can now suggest responses. Why did cattle and sheep numbers increase dramatically just as tillage was collapsing? The model predicts that the loss of endowments will increase the factor price ratio against labour. Production technique in Prefamine Ireland was highly labour intensive but with considerable possibilities for factor substitution, which the livestock change illustrated. Why did so many small farmers attempt to get onto the public works despite the wage rate being set so low that only the destitute would be tempted? At low levels of endowment the wage rate at which it was rational for a worker to participate in the labour market (and be physically capable of doing so) declined with assets, so if a destitute man could work it was in the interest of the better-off man to work also. Why did the public works fail? The attempt to use the wage as a screening device was flawed. The surge of applicants was interpreted as indicating generosity of the wage rate with the result that the poorest could not survive on the earnings they were capable of making.

\section{REFERENCES}

BIDWELL, P. W., and J.I. FALCONER, 1925. History of Agriculture in the Northern United States 1620-1860, Washington: Carnegie Institution.

BOURKE, P.M.A., 1965. "The Agricultural Statistics of the 1941 Census of Ireland, a Critical Reviewn, Economic History Review (2nd series), Vol. 18, pp. 376-391.

CLAY, E.J., 1986. "Rural Public Works and Food-for-Work: A Survey", World Development, Vol. 14, pp. 1,237-1,252.

DRĖZE, J. and A. SEN, 1989. Hunger and Public Policy, Oxford: Clarendon Press. 
GREAT BRITAIN, 1836. Reports of the Commissioners for Inquiry into the Condition of the Poorer Classes in Ireland (Poor Inquiry), Vols. 30-34.

GREAT BRITAIN, 1847. Correspondence, from July 1846 to January 1847, Relating to the Measures Adopted for the Relief of Distress in Ireland (Board of Works Series), Vol. 50.

GREAT BRITAIN, 1852. Report from the Select Committee of the House of Lords on the Treasury Minute, Providing for the Debts Due from Counties and Unions in Ireland by the Imposition of a Consolidated Annuity, 6.

KOOPMANS, T.C., 1957. Three Essays on the State of Economic Science, New York: McGraw-Hill.

MOKYR, J., 1980. "The Deadly Fungus: An Econometric Investigation into the Shortterm Demographic Impact of the Irish Famine, 1846-56" Research in Population Economics, Vol. 2, pp. 237-277.

MOKYR, J., 1981, "Irish History with the Potato", Irish Economic and Social History, Vol. 8, pp. 3-29.

O'GRÁDA, C., 1974. "Agricultural Head Rents, Pre-Famine and Post-Famine", The Economic and Social Review, Vol. 5, pp. 149-165.

O'GRÁDA, C., 1984. "Irish Agricultural Output Before and After the Famine", Journal of European Economic History, Vol. 13, No. 1, pp. 149-165.

O'GRÁDA, C., 1989. The Great Irish Famine, Basingstoke: Macmillan.

SEN, A., 1981. Poverty and Famines: An Essay on Entitlement and Deprivation, Oxford: Clarendon Press. 